DOI https://doi.org/10.36059/978-966-397-215-2/27-44

\title{
MUSIC THESAURUS COMPILING TECHNIQUE
}

\section{Kalashnyk M. P.}

\section{INTRODUCTION}

Before presenting the scientific provisions that form the theoretical basis of this subsection of our study, let us note that knowledge about music penetrates the consciousness of society and the individual in all ways accessible to a person: from image-subject with direct contemplation or perception of artistic word - to abstract-scientific. However, the very multichannel communication with musical knowledge causes the urgent need for it to be reduced to a single, compact enough document. The music thesaurus takes on this role, the creation of which becomes especially relevant in the context of the present information boom.

The music thesaurus is a document where the meaningful (informational) space of this type of art is implemented through a system of words, concepts organized in the framework of music theory and practice, in a certain organized and presented way. Subject to the complexity of musical knowledge, the ambiguity of the very concept of "music", the variety of forms of its existence, as well as the large number of related activities, it is possible to invest in the used term "information space" the content that its scholars use on a geopolitical scale, noting, in particular, that it is "the only, holistic social information phenomenon that can be considered as a set of interacting information processes and systems $<\ldots>^{\prime 1}$.

The procedure for the creation of thesauruses is described in detail in the Techniques developed by the Institute of Informatics and set out in special editions of the State Standard of Ukraine. ${ }^{2}$ We shall refer to the main provisions of these documents. The structure of a thesaurus is predetermined by its purpose: to give a brief systematic view of a

1 Berestova T.F., Information space as a result of informational process development / T.F. Berestova, Bulletin of MSUCA. - 2005. - No. 3. - P. 112.

2 State Standard of Ukraine. Information and documentation. A multilingual thesaurus: the development methodology. - Official edition - K.: State Standard of Ukraine, 2001. - 76 p. 
particular field of knowledge or practice. Compression involves, first, the reduction of a large number of phenomena to unity through their comprehension with the help of a token; second, the choice of a nonarbitrary meaning. The following claim is laid to the terms that specializes the thesaurus: "Unlike the terms in the dictionary, which can be accompanied by a number of different definitions that reflect common usage, each term of the thesaurus is rigidly tied to a single meaning that best meets the requirements of the indexing system" ${ }^{3}$. Thesaurus is a structure consisting of lexical concepts with certain relationships established between them. There are two types: a posteriori (syntagmatic, conveying the meaning of the phenomenon in a set of terms), and a priori (paradigmatic, assuming the presence of other terms). The latter are to be processed in a thesaurus ${ }^{4}$. In other words, a thesaurus "reproduces through its structure relationships that generally establish the "semantic context" of a given term, with specific references to terms with a broader or narrower connotation (additional meaning). This is usually enough to indicate a scientific interpretation of a particular term ${ }^{5}$.

An important feature of a thesaurus that distinguishes it from unstructured lists of terms, such as a dictionary, is its hierarchy, which means generic, whole-part relationships, and intance ${ }^{6}$. Finally, if the same phenomenon or concept can be defined by different synonymous terms, the most common one should be chosen ${ }^{7}$.

The above recommendations for the compilation of a thesaurus are of a general methodological nature, therefore they require appropriate mediations for their practical application in artistic creativity, and especially in such "meaningless" area as music. This is all the more important because the terminological apparatus of the humanities itself assumes a rather high degree of ambiguity and even metaphoricity. One should not forget the practice of transferring lexical concepts from one art or related discipline to another, adaptation of terminological units of philosophy, literary studies, linguistics, etc. in the content field of music science, as a result of which they acquire new semantics until a complete

${ }^{3}$ State Standard of Ukraine. Information and documentation. A multilingual thesaurus: the development methodology. - Official edition - K.: State Standard of Ukraine, 2001. - P. 7.

${ }^{4}$ Ibid. - P. 1-2.

${ }^{5}$ Ibid. - P. 16.

${ }^{6}$ Ibid. - P. 26.

${ }^{7}$ Ibid. - P. 7. 
rethink (well known examples). Thus, the question arises to the equivalence of twin, chameleon words that travel across different contextual spaces and require assistance in their proper placement in a thesaurus with regard to their formulations, through which they will be embedded in a conceptual system of knowledge. The above is very important for the fundamental terms, concepts of the art disciplines, namely, artistic direction, genre, style, method, etc., which in each of them have their own set of connotations and have different subject expressions. It should also be borne in mind that music is in direct contact with the natural and man-made habitat (acoustic phenomena of nature and civilization), linguistic communication (intonation, melody, phonetic properties of verbal language), as well as the key parameters of being (space and time), reproduced by ancient Greek thinkers in a concept-image of the music of the spheres. Saying nothing of the very nature of sound: it is studied by physics - science, far cry from the phenomenon of art. Thus, the music thesaurus should contain concepts through which at the same time the specificity of music would be revealed as a form of art and a way of indirectly engaging and broadcasting information about the structure of the culture and the universe itself.

\section{The superstuctural level of a music thesaurus}

Before making some constructive suggestions for creating a music thesaurus, we need to come up with some general guidelines. The starting point in our search for the most optimal approach to compiling a list of music-related concepts related is to understand the thesaurus simultaneously as a way of capturing (storing) it in a special form of knowledge itself, as well as encoded information about it, as a key to musicology, which is understood quite widely. In the second case, it is related to the alphabet of the verbal language or the musical sound scale of musical art, both in tempered and non-tempered tuning systems. Adding the initial moment of immersion in a certain sign system, its minimal units formed in a given order make an "elementary" level of knowledge, if we consider this concept synonymous with fundamentality rather than with primitiveness. In the same semantic section, the "primacy" of a thesaurus should be interpreted as a reduction to the system of terms of all the variety of knowledge that has arisen in sociocultural and scientific practice. 
The task of embracing the content of the music thesaurus determines the preference for a morphological approach, which, in turn, presupposes a thematic principle of arrangement of material subordinate to the hierarchical system of relationships in the course of cross-linking. In other words, encyclopedic coverage of information seems to be close for us, however, without alphabetical order and without explanatory remarks and, moreover, without detailed articles. According to the structure of a music thesaurus, the dictionary includes three levels of concepts: "superstuctural", "basic", and one that appeals to the musical-sound realities of routine life ("background"). The first combines concepts contained in the fields of science, education, enlightenment, sociocultural ways of existence of musical forms, that is, with those fields of activity that are powered from music, but do not directly belong to its "body". The "basic" level of knowledge otherwise implies immersion in the music plane and comprehension of music as a phenomenon. The mediators between the "top" and "bottom" of the emerging structure are the individual activity forms associated with the creation of notationgraphic and sonar-background text. The composer and performer "shape" the musical fabric, control its movement, and are involved in the mysteries of musical being, but also exist outside it (the fabric), rather simulating a complete dissolution in it, which should be understood only metaphorically. The musical-sound environment creates the acoustic atmosphere of the present and is confronted with the phenomenon of the musical as a conductor of the non-musical, which feeds the music with immediate life impressions and implements its cognitive function.

Since the 'superstuctural' layer of the thesaurus refers to the knowledge gained in connection with music, it is advisable to group the first subject block around the keyword 'science'. Words combined thereunder can be alphabetical and meaningful. In the first case, they form a simple series, and in the second, - a system of relationships that is preferred to the thesaurus dictionary. Based on the above, the registry of "science" should be headed by the fundamental branches of musicology: music theory with deciphering (elementary theory, harmony, polyphony, instrumental studies, analysis), as well as its history, including the history of orchestral styles, study of local lore, and archival studies. Considering that musical art is not limited to composer work and includes performing arts, it is necessary to add to the third line of the list of terms of this block the discipline title "Theory and History of Performing Arts" with its partial divisions (history of pianism, playing the string, wind, percussion instruments, as well as vocal, orchestral, conductor, capella, choral and 
other arts). In our opinion, fundamental subjects are also the pedagogy and teaching methods of musical subjects (theoretical, historical, performing). Given the active development of the contemporary stage of musical liturgy due to the ever-growing interest in the spiritual-singing templar art, it can also be considered as a fundamental field of science. This also includes folklore treated as a methodological basis for the study of specific realities and the phenomenon of oral folk music-aesthetic worldview. Other areas of science, which are more or less established, are a combination of specifically musical and other problems. Musical semiotics, semantics, psychology, sociology, aesthetics, and philosophy of music have emerged at the intersection of different scientific disciplines. The latter two are maximally abstracted from the "body" of music by virtue of their appeal to the highest, generalized conceptual layer of cognition, thereby bringing musicology to the sphere of philosophical problems. This register of terms would feasibly include scientific and source studies, which make it possible to understand, on the one hand, the regularities of the movement of knowledge about music, and, on the other, to systematize their greater achievements. Bibliography is a special instrument of music science as an instrument for solving this problem. It is no exaggeration to say that this part of the "science" registry forms a bundle of affiliated lines of musicology, the number of which is easy to increase.

Following the laws of logic, the second thematic block of the thesaurus should be devoted to education, i.e. to the institutions where the knowledge of music is transmitted. At the same time, given the specific information and sound nature of music, which determines its existence in two forms (oral and written), the field of education is aimed at acquiring performing professionalism, that is, the instrument or voice mastering skills. Higher music education is taken as a basis, so this part of the register should be legally occupied by higher education institutions: conservatories, academies of music (music academy), institutes of arts, music and drama institutes, music and pedagogical colleges (universities, institutes), universities of arts, universities of music, departments of pedagogical institutes and universities. The list of these educational institutions can follow both hierarchical and alphabetical principle of naming. This part of the register is associated with the words-meanings of secondary and elementary specialized and non-specialized education units: children's music school (CMS), a a study group, an art lyceum, music classes in a secondary school, a music school, a ten-year music school. 

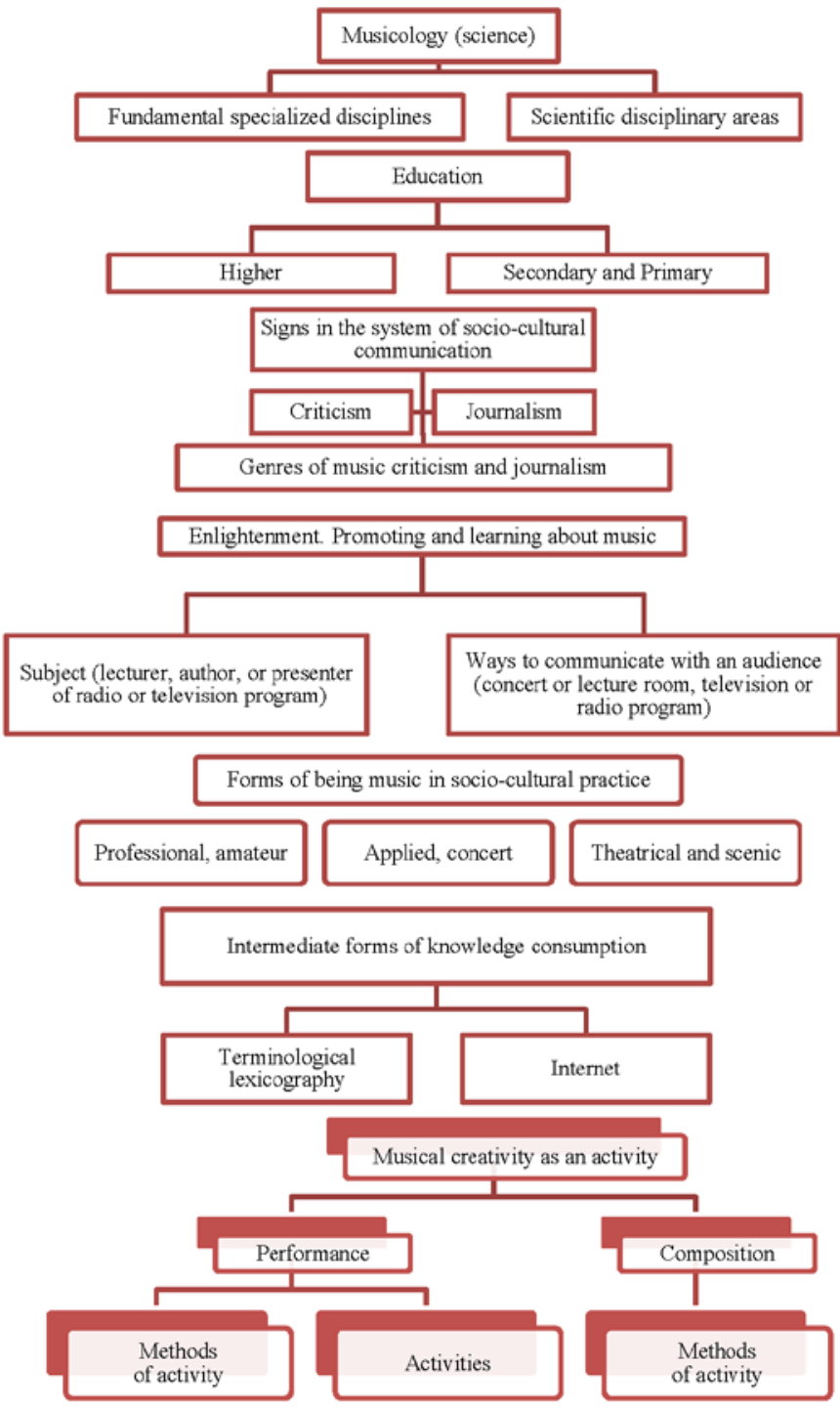

Means of storage of musical knowledgectice

Sheet music and books (handwritten and published texts in hooks, snares, banners, etc.)
Book and record libraries
Audio and video

Figure 1. The superstuctural level of a music thesaurus 
Given that music functions in a particular communication system, music criticism and journalism belong to the third thematic block. Both of these activities brought to life an extensive system of genres, the names of which should appear in the thesaurus (a survey, abstract, problematic article, review, creative portrait, booklet, interview, radio and television broadcast, etc.). Bearing in mind that these disciplines may be related to music science, it is advisable to use the experience of K. Schneider's Thesaurus and provide a "see also" note here, thus sending the user to the first thematic block of the dictionary.

As the attention of music criticism, and especially of journalism, is drawn directly to the public's need for works of art, it may be considered natural to move to a group of terms that they have formed about education (the fourth thematic block). It includes the concepts "lecturer", "popular lecture", "lecture-concert", "preface". This content line has relation to music journalism, so again, the "see also" note is appropriate.

We should note that the possibility of assigning the same words to different headings demonstrates the presence of horizontal and cross-link relations next to vertical ones, which makes the structure of the thesaurus more multidimensional. The above applies not only to individual terms within the registers, but also to the names (verbal designations) of thematic blocks. Thus, "Enlightenment" intersects, on the one hand, with "Science" and "Education", and on the other - with different forms of music being in socio-cultural practice.

The fifth thematic block contains secular and spiritual, professional and amateur, applied and concert, as well as various theatrical and stage ways of implementation of musical creativity.

The intermediate position between cultural and scientific consumption is occupied by the sixth thematic block, which includes various reference and encyclopedic editions: various dictionaries, music lexicons, mono- and multi-volume encyclopedias, the Internet system.

As far as the subject point of view is concerned, music implies, in addition to scientific or amateur knowledge of it, artistic creation itself the seventh thematic block, which in turn is divided into two large subgroups. One of them - "performance", includes the terms "reproduction", "interpretation", "improvisation", defining the content of performing activities, as well as the concepts of "performing style", "school", "tradition" - terms in the field of professional culture. The same group includes performances (solo, ensemble, choral, orchestra, vocal and instrumental) with their consecutive names (duet, trio, quartet, quintet, sextet, septet, octet, nonet; jazz band, rock band, VIA; "triadic music", 
etc.). The second subgroup includes the concept of "music making" - it means "production" of original works (opuses), "improvisation", "harmonization", "arrangement", "transcription", "instrumentation", "orchestration". There are also cross-links between these subgroups. First, the history of music knows several examples of combining in one person the performer and the composer - up to the considerable rethinking of his own opus in the concert program, as, for example, was characteristic of S. Rachmaninov; secondly, performers, including heads of choirs and orchestral teams, successfully manage the harmonization or translation process; and, finally, in the third place, such a form of activity as improvisation can equally belong to the performance as well as to the creation, since in the course of its implementation the musician simultaneously "composes" the intonation-sound text and offers it to the audience. We should add that when creating in the genres of etude, concert, transcription, fantasy, etc., the composer often pursues not only his own compositional and dramatic goals, but also provides for performing, which allows the instrumentalist to demonstrate virtuosity. Similarly, the opera composer often densely captures bellicose roulades into the text of the aria, saturates the tunes with broad jumps, extends the soundtrack, relying on the attention of the diva. At the same time, the author of the musical works does not lack the desire to demonstrate his own skill, ingenuity in creating unique samples of art, introducing unexpected sounds, methods of development, unexpected intonational, structural combinations, etc. In other words, specific artistic tasks, demonstration aspects of creativity that bring together the art of composition and performance may come to the fore. However, we should not forget about the equal desire of the author of musical works to summarize his own observations on the intonational and logical patterns of music, as evidenced by more than one generation of theorist composers who have created many epochal in their significance of scientific works: from "Treatise on Harmony reduced to its natural principle" by JeanPhilippe Rameau to "The Moving Counterpoint of Strict Letter" by S. Taneev. Thus, another link is found between the various thematic blocks of the music thesaurus vocabulary, and more broadly, between the various concepts grouped around the generic term "music".

Performing and composing forms of activity naturally require a transition to their carriers. These include musicians who work in various fields of creativity. In the academic tradition, this is, in particular, the instrumentalist, vocalist, choir or orchestra artist, bandmaster, conductor, composer, arranger, harmonizer (translator: for example, in temple 
singing), etc. In the folklore tradition, representatives of various national professional singers-narrators (akin, kobzar, guslar, etc.), participants of calendar and ceremonial activities, individuals involved in daily affairs, and others can be named. In various forms of so-called light music, we can distinguish jazzmen, rock musicians, creators of the song or its performers, members of the ensemble, etc.

Performing and composing products are stored and transmitted through various means of communication and technology: in oral form (word of mouth), visual-written, book (music, mute, hooks, banners, special marks in music of European avant-garde), audio and video. This is the eighth block of terms, which puts all the previous ones at risk. These include repositories of scientific knowledge (books), periodicals, as well as music and record libraries. It should be recalled that the reference books were discussed above, and they found their place in the second block, given their direct relation to the education sector. Concerning scientific, educational literature and periodicals, they correspond at the same time with the ways of storing knowledge and production: the creation of music, its study and the transfer of experience. Thus, the entire structure of the "superstructure" part of the thesaurus is symmetrically rounded, closing the top and bottom levels of cognition.

To visualize the proposed hierarchical structure, we present its specific system of relationships using the scheme below (Fig. 1).

\section{The "basic" part of the music thesaurus}

The "basic" part of the music thesaurus consists of two subdivisions. The first of these can be called "Music as Art" and the second - "Music as Phenomenon". It opens this hierarchical pyramid of the concept of "music", which combines a large number of manifestations of musical. In particular, it is the music of the academic tradition, folklore, varieties of entertaining types of music, author's song, city romance, etc. The conditional name of the first thematic block - "Music and Musicians". Already, there is a clear heterogeneity of meaningful content of the concept of "music". For example, in folklore, music is almost invariably fused, first, with a word or dance, and, secondly, with some practical action: routine or ritual-magical. It should be clarified that this is about the folk creativity of the oral tradition in its original habitat, and not as a folk ensemble on the concert stage. Similarly, pop genres are most often associated with singing, that is, again with the verbal series, and in modern practice - with dance, not to mention that the entertainment 
subculture does not exclusively involve listening experience, easily turning into dance accompaniment or even a means of creating a particular atmosphere for leisure at home or at the disco. As for academic music, it is also willing to come into contact with non-musical modes of expression with preserving its "name", as is often the case, for example, in the name of "vocal" music, where, quite naturally, the word is involved. This requires the selection of the second thematic block of the "basic" level of the thesaurus, which is conventionally defined as "Quality states of music". It includes so-called "pure" music, that is, that exists without the participation of non-musical factors; program, accompanied by a verbal subtitle, which refers us to all kinds of depicted, literary, landscape and other realities of the artistic and natural environment; theatrical (including music for dramatic performance), cinema, and word-related. In turn, the interaction of the musical and the performing arts has undergone multiple changes over the course of the historical development, and as a result, they can be incorporated into the context of both the musical and theatrical thesaurus. For example, in opera, the main component of synthesis is music, and in a play, even with a developed musical series, on the contrary, it is a performance (in "theater of show" - acting).

Thus, the first two thematic blocks decipher the range of meanings that are included in the generalized notion of "music". Another criterion for its differentiation the aesthetic factor acts in is revealed in evolutionary projection. It is linked to the third thematic block of the thesaurus, covering the general categories of art: artistic trends and historical (landmark, national, individual) styles. If the complete list of the former can be regarded as quite acceptable to the thesaurus due to the relatively small number of names, then among the latter only large epochal phenomena can be distinguished, which nominally coincide with the artistic directions. With regard to national and, moreover, individualauthor styles, this series is headed for virtual infinity, so it cannot claim even relative exhaustiveness.

A number of general aesthetic categories continues the fourth thematic block: genres. Given that this concept has a dual meaning in the music of the academic tradition and related scientific knowledge the type of work and the primary manifestations of the musical, inseparable from material practical activity, it is advisable to distinguish two lists of terms, one of which was formed in line with the New European professional "Written" music, and the second entered it from the outside, from the amateur, folklore and urban living environment and 
sowed in the "high spheres" of musical art an equal place. However, given that the primary genres are originally applied or semi-applied, it is appropriate to duplicate this list in the third block of the thesaurus with a "see also" note.

In listing the genres of academic music, it is best to adhere to the hierarchical principle of arrangement of concepts in accordance with their sequence under the generic "names" of "pure", programmatic, etc. music, adhered to in the second block of the "basic" layer of the thesaurus, which first lists the genres of "pure" instrumental music, then - programmatic, etc. In this case, it is appropriate to exclude the term "music for dramatic performance" that has no genre content. It should be noted, by the way, that this kind of musical art, as well as cinematic music, can also be attributed to the third, background, level of the thesaurus since under such conditions it acquires an applied value.

Given that the equivalent of "pure" music is the instrumentalism of the academic tradition, the largest fifth block of terms combined by the name "Performing Forces" should be headed by the "Orchestra" heading with the decipherment "symphonic", "chamber", "string", variety"," variety and symphony”, "jazz orchestra”, "folk instrumental orchestra”, "baroque instrumental chapel", as well as determining the composition of each. Behind it is the section "Chorus" with clarifications (female, male, children's, mixed, boy choir). These registers are supplemented by lists of "Other instruments" and "Vocal roles". Here again the question arises as to the exhaustibility of the titles of first and foremost instruments that are virtually indistinguishable. A great degree of completeness of information is provided by vocal roles, a number of which are available for review.

The next, sixth thematic block contains the concepts "composition", "dramaturgy", "musical forms" under the general name "Logical laws of the musical text organization". More detailed deployments require "Musical forms", which mention the main, located from complex to simple: cyclical ("sonata-symphonic", "suite", "party", "small", "variational", "concert" forms), contrasting component, sonata, rondo, couplet, two and three parts, period, as well as baroque specimens ("invention", "fugue", "fugato", "concert", etc.).

The methods and ways of musical presentation and development are called expositional, developing, motive development, variant-variational development, imitation, counterpoint, subheading, contradiction, canon, stretto. They include terms that denote sections of the form, such as "exposure", "development", "reprise", "episode", "trio", “interlude”, etc. 

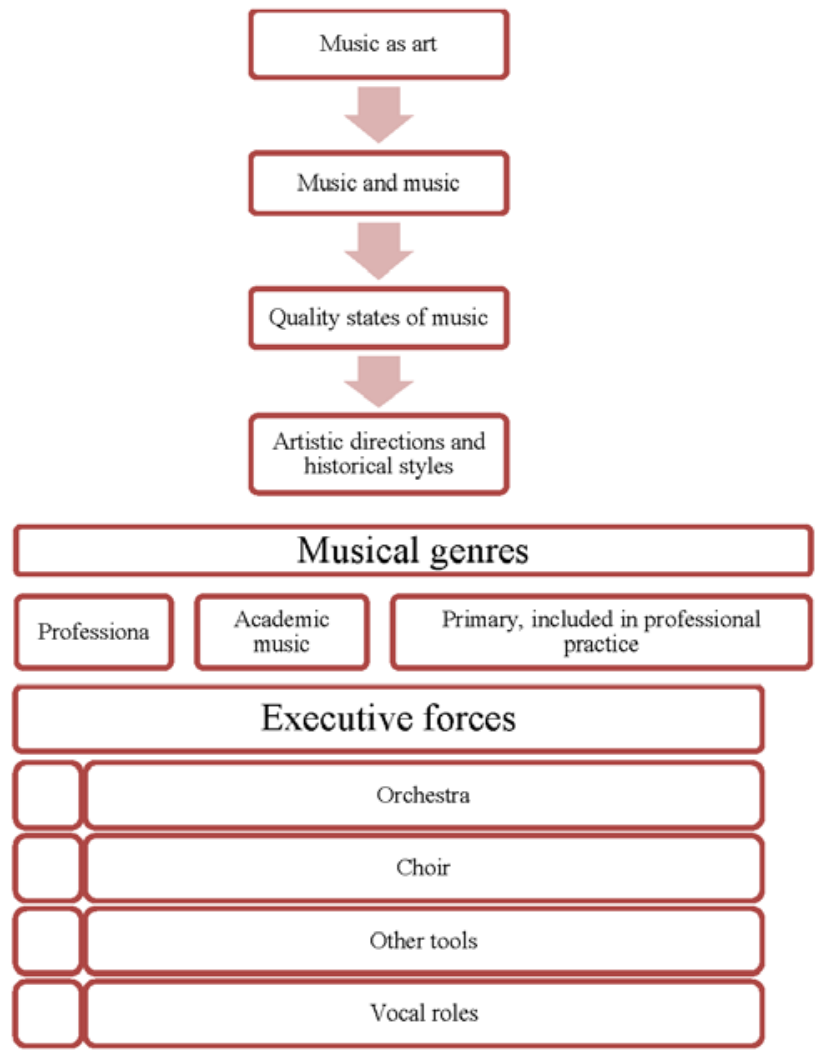

Logical patterns of organization of musical text

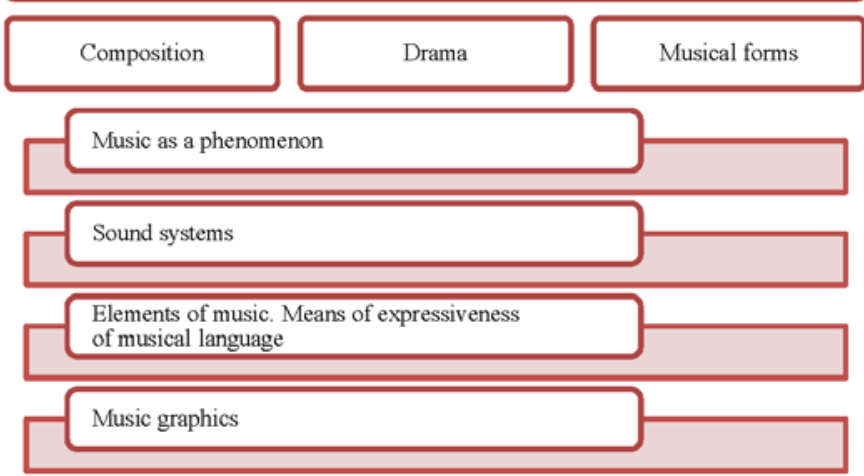

Figure 2. The basic level of a music thesaurus 
As we can see, the first section of the "basic" level of the thesaurus makes a consistent transition from more general, even non-specific, concepts to more specific, musical ones. The conceptual apparatus presented in the last thematic block transfers the thesaurus arrow to the second subdivision of its "basic" layer. It opens with the first thematic block "Sound systems", containing the concepts of "classical harmony", "tonality" (including, expanded XX century), "image", "sound system", "gamma", "modality", "seriality", sonoric-phonics principles". The next, second thematic block is "Elements of music. Means of musical language”. The terms "musical sound", "tone", "intonation", "motive", "phrase", "theme", "melody", "harmony" are involved here - with the "see also” note, "polyphony", "texture", “timbre", "register", "meter", "rhythm", "tempo", "loud dynamics", "articulation". The second subdivision of the "basic" part of the thesaurus is completed with the third thematic block of terms called "Musical graphics", where, in addition to music and other signs, indicating the absolute pitch or directionality of melodic movement ("mute", "hooks", "banners", etc.), which includes the whole set of definitions worked out by the art of music: "phrasing league", “fermata", "reprise sign", "pedal", "accolade", dynamic "fork", signs of raising or lowering tone, "fingering" etc. This may include the concepts of "digital bass", "party", "score", "basso continuo", remarks in $A$, in $B$, in $F$, etc. The written, "book" hypostasis of music creates the conditions for its scientific study and awareness. Thus, immersion in the "body" of music leads to the return of the cognitive act to its original position, closing the thesaurus dictionary into another, larger circle.

To complete the idea of the ratio of thematic blocks of the "basic" level of the thesaurus we draw the following scheme (Fig. 2).

\section{The background level of a music thesaurus}

The "background" level of the music thesaurus contains two thematic blocks: "Musical sounding" and "Extra-musical sounding" under the general name "Routine sound environment" (Fig. 3). This is the sphere that supplies music with material for aesthetic processing and emotional awareness, namely the outside world, which is absorbed by individual and collective subjects.

The first block, in turn, is divided into applied and background music. The latter refers to musical sounds that create an acoustic atmosphere of urban topos. 
Similarly, the second block has exits to the urban and natural sound spaces that are reflected in the music arts. It should be noted that all this level of thesaurus corresponds in its essence with K. Schneider's Thesaurus.

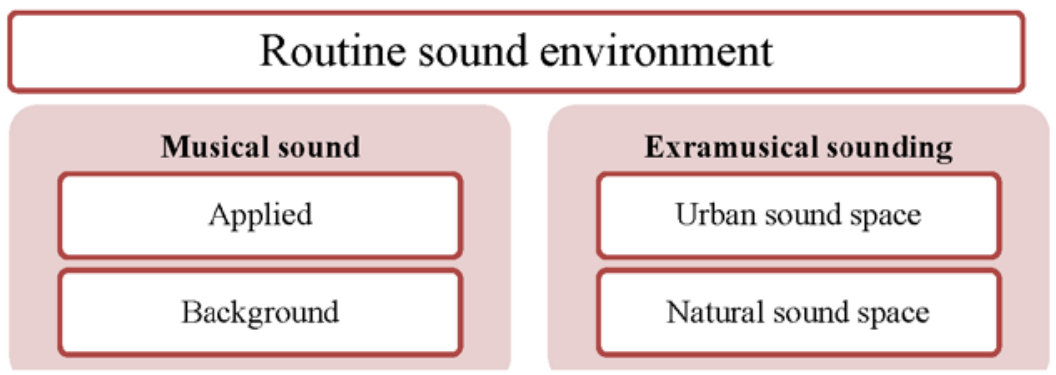

Figure 3. The background level of a music thesaurus

To sum up, let us say that both forms of being of units of knowledge - oral and written - focus on a single subject and have similarities in structure, divided into hierarchically subordinated levels: "superstructural", "basic", and "background". However, the characteristics of the information embedded in each of these forms are not identical since the transition from one state to another is a change of concepts, and the content of each level changes significantly. The "superstructural" part of a set of data stored in the mind means knowledge about music, that is, information related thereto, but is on the verge of conceptual and intuitive-sensory. In the thesaurus, it is corresponds by information that goes beyond musical art to a wide field of culture, testifies to the sources of its cognition, as well as masters the effective forms caused by its content. At the same time, this part of the thesaurus in its oral version also includes knowledge encrypted in the system of terms, located in the "basic" section. Because it is a written document, the vocabulary cannot include directly the auditory impressions encoded in the intonation system of music, as well as the aesthetic and emotional experiences arising from direct contact with musical sound, since the material substance of this art generates such a meaning in translatable into words. That is why the "basic" parts in both forms of the thesaurus do not coincide. If it is created orally by specific musical knowledge (knowledge of the music itself), then in writing it is a terminological apparatus that has historically evolved in 
musical theory and practice. The same applies to the "background" level of the thesaurus, which in one case is related to auditory impressions and reactions occurring directly, and in the other, to their conceptual awareness. In other words, with all the differences in the levels of knowledge of the thesaurus, the information contained in it is arranged in a single sign and cognitive projection because they create a certain information aura around the music and provide insightful ideas about its essence.

The difference between the oral and written forms of the thesaurus implies the purpose of the dictionary as a document and its pragmatic significance. They consist of its special gestalt quality, which allows the user to quickly reach the boundaries of the object being studied, as well as its conceptual field, acting at the same time as a means of primary contact with the subject of knowledge, as well as with a collapsed way of knowing about it. We reiterate that the thesaurus does not claim to be complete information about music or the accuracy of scientific definitions and, moreover, to explain the terms. It only orientates within the existing information space within it, and also sets a certain direction in the search for knowledge. Comprehensive data about music as art, intonation-sound phenomenon, way of comprehending reality, its internal laws and history, the user can obtain in scientific, popular, reference publications, didactic literature, as well as on the Internet, that is, in numerous material forms of music thesaurus. It is equally important to the music consumer that a thesaurus dictionary provides the key to understanding this type of artistic creativity as a particular organism, the penetration of which, for the sake of its knowledge, requires the necessary level of preparation. Thus, the dictionary is able to promote the process of cognition itself. It also helps to find sources of interest, relevant activities and ways to get music education. Finally, the dictionary contributes to the understanding of the multidimensionality of music as a form of art, its heterogeneity in terms of quality, nature of content and functional orientation.

Therefore, the concept of "music thesaurus" is subject to further development. If the first stage of this process involved the disclosure of forms of the thesaurus as a repository of musical knowledge, the focus now is on the structure of this repository, that is, the definition of its constituent units and their relationships. These are, therefore, those divisions of musical knowledge that systematize single representations, impressions, and facts, ensuring the semantic unity of the space of the music thesaurus. 
Both ideal and material forms of music thesaurus retain their relevance for solving research problems, since they have a general methodological character and allow, on the one hand, to enter music into a broad sociocultural context, presenting it as a carrier of intra- and extramusical information, and on the other - to record the fact of structured knowledge (both on different kinds of material carriers, as well as in the consciousness of the collective and the individual). At the same time, the study of the structure of a music thesaurus required the introduction of a different classification, namely, its division into oral and written forms. The first means those units of knowledge that have an ideal and material expression and are fixed in the memory of the collective and the individual; the second is a written projection of the oral, which is embodied through the thesaurus.

\section{CONCLUSIONS}

Music, like any other object of the world of nature and culture, is in the zone of cognitive aspirations of man, as a result of which the system of naming its elements, methods of studying its laws and the very essence itself develop. Thus, there is a "superstructural" knowledge of expanding music, acquiring verbality, formality, and being outlined in various ways of description. In this form, it is readily available for written fixation, the ideal means of which is a thesaurus-dictionary-a documentary display of units of storage of musical knowledge. Therefore, in terms of storage units, the music thesaurus is divided into oral and written.

The question naturally arises as to the forms of knowledge storage. Two forms of music thesaurus are distinguished: the ideal and the material, each of which has several types and modes. In this case, this is in line with the general conception of thesaurus produced by computer science and linguistics, since any knowledge is stored in the collective and individual consciousness, on the one hand, and on various carriers, on the other. And yet, the music thesaurus also manifests its specificity in this regard, applying the special character of embodiment. In an ideal form, it finds its manifestation in fixing the experience of perception and communication through the auditory channel of communication, communication through the music, general ideas about it, "traces" of musical and predetermined impressions, sound images, fragments of music material, and sometimes the whole work in the memory of a professional musician and an educated amateur; material form manifests itself in records, in particular graphic, which has its own historical 
variations, and electronic / mechanical, as well as verbal notes and symbols contained in sheet music, books of various profiles, materials and documents that reveal facts and circumstances creative biography and personal qualities of the composer or performer (including memoirs, diaries, letters), in figurative samples and in canvases of painting. Thus, a system of thematic blocks emerges, the selection of which creates a classification base for compiling a thesaurus. It should be noted that in the aspect of information storage, the oral existence of music as a sound phenomenon, which is perceived by the hearing organs, is included in the material form of the music thesaurus; on the contrary, the "superstructural" part of it implies the knowledge stored in an ideal form, that is, in the minds of the collective and the individual.

\section{SUMMARY}

The article considers information retrieval language, which allows for prompt entry into the semantic parameters of subjects in the humanities. The method of compiling a musical thesaurus and dictionary is given.

\section{REFERENCES}

1. Берестова Т. Ф. Информационное пространство как результат развития инфопроцесса / Т. Ф. Берестова // Вестн. МГУКИ. - 2005. № 3. - С. 106-13.

2. Государственный стандарт Украины. Информация и документация. Многоязычный тезаурус: методика разработки. Изд. офиц. - К.: Госстандарт Украины, 2001. - 76 с.

3. Государственный стандарт Украины. Информация и документация. Одноязычный тезаурус: методика разработки. - Изд. офиц. - К.: Госстандарт Украины, 2001. - 60 с.

4. Жмайло С. В. К вопросу об определении тезауруса / С. В. Жмайло // Науч.-техническая информ. Сер. 1. Орг. и методика информ. работы. -2003. - № 12. - С. 20-25.

5. Жмайло С. В. К разработке современных информационнопоисковых тезаурусов / С. В. Жмайло // Науч.-техническая информ. Cер. 1. Орг. и методика информ. работы. - 2004. - № 1. - С. 23-31.

6. Казанцева Л. П. Коммуникативная направленность музыки с тематическими заимствованиями / Л. П. Казанцева // Музыкальное произведение в системе художественной коммуникации: межвуз. сб. -Красноярск: Изд-во Красноярского университета, 1989. C. $110-128$. 
7. Каптерев А. И. Информация социокультурного пространства / А. И. Каптерев-М. : ФАИР-ПРЕСС, 2004. - 512 с.

8. Шейко В. М. Концептуальні основи освіти як соціокультурного феномену в умовах глобалізації / В. М. Шейко // Інформаційно-культурологічна та мистецька освіта: стан i перспективи: матеріали наук.-практ. конф., 12-13 жовтня 2004 р. I Харківська держ. акад. культури. - Харків, 2004. - С. 121-123.

9. Шейко В. М. Культура. Цивілізація. Глобалізація: (кінець XIX - початок XXI ст.): моногр.: у 2 т. - Т. 1. / В. М. Шейко. Харків: Основа, 2001. -520 с.

10.Шейко В. М. Організація та методика науково-дослідницької діяльності: підруч. для вузів / В. М. Шейко, Н. М. Кушнаренко. Харків: ХДАК, 1998. - 228 с.

11.Шейко В. М. Формування основ культурології в добу цивілізаційної глобалізації: (друга половина XIX - початок XXI ст.): моногр. / В. М. Шейко, Ю. П. Богуцький. -К.: Генеза, 2005. -592 с.

\section{Information about the author:} Kalashnyk M. P., Doctor of Fine Arts, Professor, honoured artist of Ukraine, Head of the Musical and Instrumental Training department H.S. Skovoroda Kharkiv National Pedagogical University 29, Alchevskikh str., Kharkiv, 61002, Ukraine 